\title{
Analysis of corrosive environmental factors of seabed sediment
}

\author{
HOU BAORONG*, SUN HUYUAN, ZHANG JINGLEI, GUO GONGYU and \\ SONG JINMING \\ Institute of Oceanology, Chinese Academy of Sciences, Qingdao 266071, P.R. China
}

MS received 30 May 2000; revised 2 January 2001

\begin{abstract}
The corrosivity of seabed sediment at spots at different distances from seashore was studied based on in situ investigations in the northern sea area of the Yellow River mouth. The results show that there is close relation between distance from seashore and corrosivity of seabed sediment.
\end{abstract}

Keywords. Seabed sediment; corrosion; environmental factors.

\section{Introduction}

The corrosion due to seabed sediment is an important branch of corrosion research. The problem of metal corrosion in seabed sediments has become more and more important with developments in marine oil exploitation and communication for installations such as marine oilplatforms, man-made islands, seabed oil pipelines, communication cables, etc. We know that marine corrosion environment is divided into five zones: marine atmosphere, splash zone, tidal zone, immersion zone, and seabed sediment zone. Because of the much varied topography and landforms and sampling techniques, there is relatively little research on corrosion in seabed sediment. This article reports results of analysis and comparison of data collected by the 'Yellow River 86' survey vessel in the northern sea area off the Yellow River mouth.

\section{In situ sample collection and data reduction}

Figure 1 shows the sampling stations in the sea area $37^{\circ} 28^{\prime} \sim 38^{\circ} 28^{\prime} \mathrm{N}, 118^{\circ} 33^{\prime} \sim 119^{\circ} 20^{\prime} \mathrm{E}$ where the survey vessel 'Yellow River 86' collected a $40 \sim 60 \mathrm{~cm}$ long sediment core using a tubular sediment sampling device. Once on board, the sediment core was divided immediately into layers. The top $30 \mathrm{~cm}$ of the core was divided into $5 \mathrm{~cm}$ thick layers; from $30 \mathrm{~cm}$ downward, the core was divided into $10 \mathrm{~cm}$ thick layers. $\mathrm{pH}, E h$ and $E s$ of the sediment were measured after insertion of glass electrode, platinum electrode, $\mathrm{Ag}-\mathrm{Ag}_{2} \mathrm{~S}$ membrane electrode and saturated calomel electrode. Fe in the wet sediment was measured by the EDTA capacity method in order to calculate and obtain the $\mathrm{Fe}^{3+} / \mathrm{Fe}^{2+}$ value. The sample was sealed and transported back to land, and its water content was measured at $105^{\circ} \mathrm{C}$ by evaporation. After drying and

\footnotetext{
*Author for correspondence
}

grinding the sediment, the content of organic carbon in it was measured at $70^{\circ} \mathrm{C}$ by the $\mathrm{H}_{2} \mathrm{SO}_{4}-\mathrm{K}_{2} \mathrm{Cr}_{2} \mathrm{O}_{7}-\mathrm{Fe}^{2+}$ capacity method. All the errors were not over $\pm 3 \%$.

Figure 1 shows D section with 5 sampling stations. We discuss below the effects of corrosive environmental factors on this section's 5 stations as representative of all the other study area stations. Along the direction from D1 to D5, the distribution of water content in the sediment varied greatly. Water content of the sediment close to the seashore was low, and that far from the seashore was high. The surface sediments from D1 to D5 stations were in consecutive layers in the order: coarse sand, coarse sand, fine sand, sandy clay and clayey soft mud. But for the $10 \sim 15 \mathrm{~cm}$ layers, they were in the order: coarse sand, coarse sand, fine sand, fine sandy and soft mud.

\section{Distribution of corrosive environmental factors}

$\mathrm{pH}, E h$ and $E s$ are characteristic parameters of sediment as well as main environmental factors of its corrosivity. Figure $2 \mathrm{a}$ on the relation between $\mathrm{pH}$ value and distance from seashore shows that the $\mathrm{pH}$ value of sediment near the coast was the highest and decreased with increasing distance from coast up to a distance of $14 \mathrm{~km}$, but increased again with distance slowly. The in situ survey finding showed that the $\mathrm{pH}$ value of sediment at the mouth of the Yellow River was in general low, which is caused by the decomposition of a large quantity of organisms transported from the Yellow River. The $\mathrm{pH}$ value is an important factor affecting steel corrosion. Decrease of $\mathrm{pH}$ directly leads to acceleration of corrosion. At the same time, the $\mathrm{pH}$ value determines directly the dissolution and existing form of elements in sediment and porewater, and plays an important role in the corrosion behaviour of steel in sediment.

Figure $2 \mathrm{~b}$ shows the change in oxidation-reduction potential, $E h$ with distance from shore. Usually, the lower the $E h$ value, the more reducible the environment tended 
to be; otherwise it will tend to be oxidizable. The figure shows a high $E h$ near the bank of the old Yellow River. With increasing distance from the coast, the $E h$ value decreases steeply; but remains steady at $90 \mathrm{mV}$.

The $E s$ of the $\mathrm{Ag}-\mathrm{Ag}_{2} \mathrm{~S}$ membrane electrode versus that of the hydrogen standard electrode was also an important indicator for evaluating environmental corrosivity, which has a linear correlation with the negative logarithm of sulfur ion concentration in porewater. The change in Es with distance from shore was much smaller than that of Eh (see figure 2c). Es changed little near the coast, increased offcoast, and decreased with depth. This is different from the distribution in $E h$, showing that the effect of sulfide alone on $E h$ was not obvious. It also shows the complexity of $E h$ controlling factors.

Figure $2 \mathrm{~d}$ shows that with increasing distance offcoast, $\mathrm{Fe}^{3+}$ first tended to increase up to a certain value and then decreased to a minimal value at $20 \mathrm{~km}$ from shore, from where it decreased rapidly seaward, but at the deep layer, this increase in $\mathrm{Fe}^{3+}$ was not obvious. Figure 2e shows that the surface layer $\mathrm{Fe}^{2+}$ increased seaward to a maximum of $5.2 \mathrm{mg} / \mathrm{g}$ at $14 \mathrm{~km}$ offshore, then decreased slightly to an almost steady value. But at the $10-15 \mathrm{~cm}$ layer, $\mathrm{Fe}^{2+}$ increased linearly seaward. Figure $2 \mathrm{f}$ shows that at the surface layer, the $\mathrm{Fe}^{3+} / \mathrm{Fe}^{2+}$ value was about 0.8 near the coast, and decreased seaward to a minimum at about $18 \mathrm{~km}$ from the shore and then increased rapidly. Moreover, that for $10-15 \mathrm{~cm}$ layer, the $\mathrm{Fe}^{3+} / \mathrm{Fe}^{2+}$ value of 0.85 at about $12 \mathrm{~km}$ from shore decreased seaward to about $0 \cdot 65$.

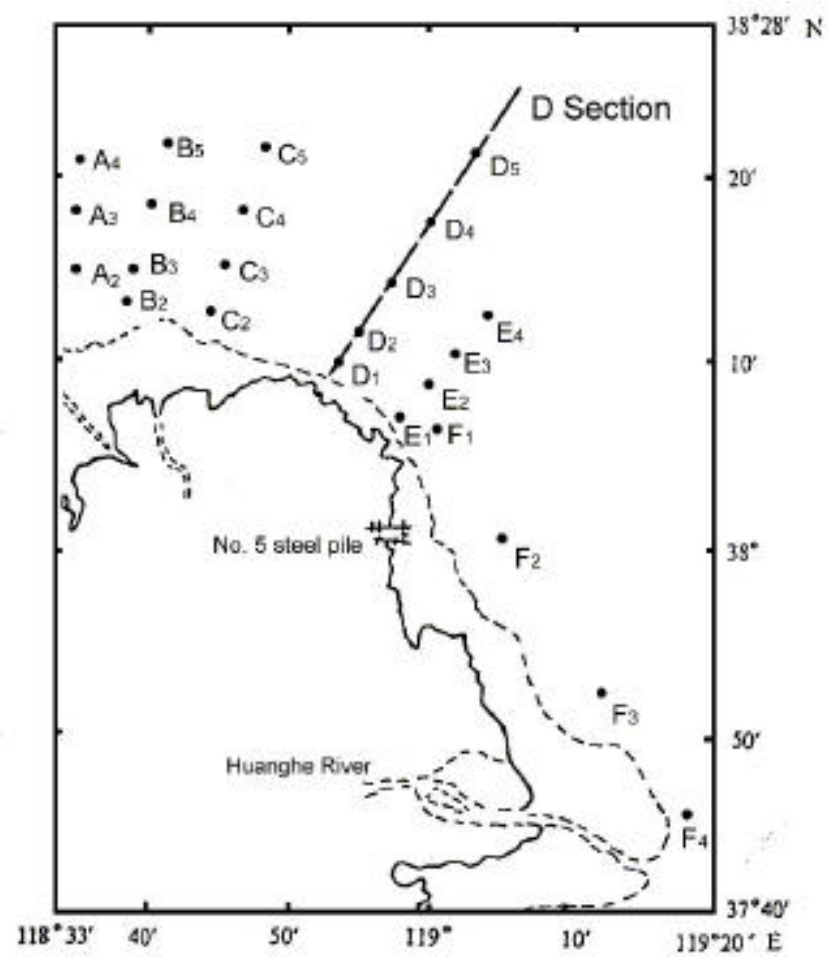

Figure 1. Sediment sampling stations in the northern sea area off the Huanghe River mouth.

\section{Corrosive environmental factors and oxidation-reduction environment}

The oxidation-reduction degree is used for evaluating the oxidation-reduction environment of the sediment, and is directly related to the oxidation-reduction potential $E h$, potential of the $\mathrm{Ag}-\mathrm{Ag}_{2} \mathrm{~S}$ membrane electrode $E s$, and the cube root of the $\mathrm{Fe}^{3+} / \mathrm{Fe}^{2+}$ value, and is inversely related to the particle size $\left(\varphi, C_{\text {org }}\right)$ as expressed by the equation:

$$
R O D=\frac{E h \cdot E s \cdot\left(\mathrm{Fe}^{3+} / \mathrm{Fe}^{2+}\right)^{1 / 3}}{\left(\varphi \cdot C_{\text {org }}\right)} .
$$

Based on the ROD, the environment can be divided into an intense reduction area for $\mathrm{ROD}<0$, a moderate reduction area for $0<\mathrm{ROD}<5$, weak reduction area for $5<$ ROD $<15$, weak oxidation area for $15<$ ROD $<30$, an increased oxidation area for $30<\mathrm{ROD}<300$, and an intense oxidation area for ROD $>300$.

Figure 3 shows the depth distribution of ROD in the D section of figure 1 . The mud layer at D1 and D2 stations were shallow and entirely within the oxidation area.

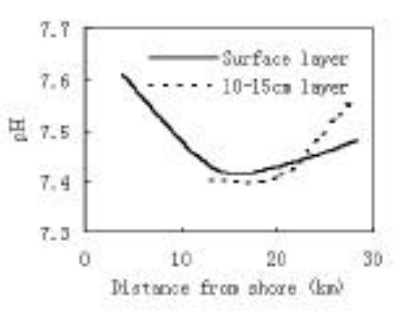

(a)

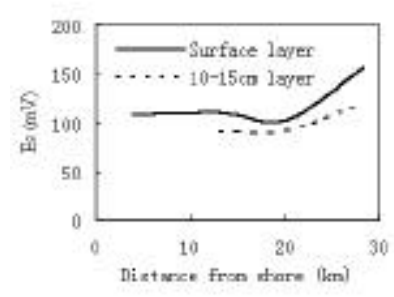

(c)

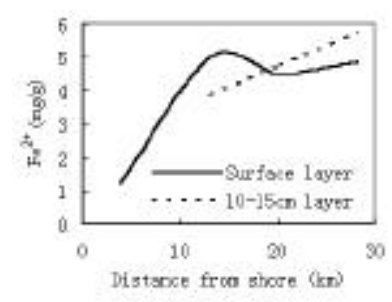

(e)

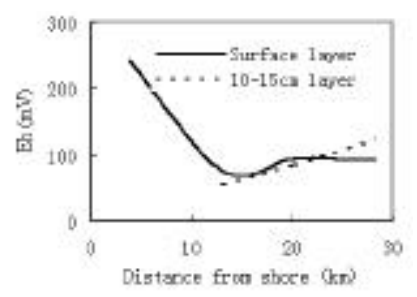

(b)

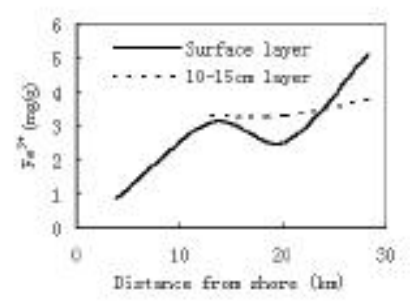

(d)

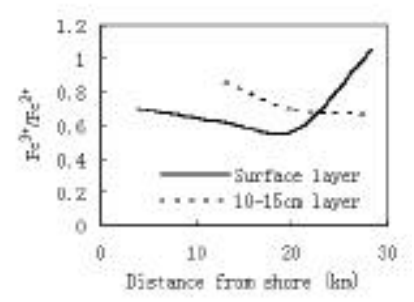

(t)
Figure 2. Distribution of environmental factors of seabed sediments along D section (a) change in $\mathrm{pH}$ with distance from shore, (b) change in $E h$ with distance from shore, (c) change in $E s$ with distance from shore, (d) change in $\mathrm{Fe}^{3+}$ with distance from shore, (e) change in $\mathrm{Fe}^{2+}$ with distance from shore, and (f) change in $\mathrm{Fe}^{3+} / \mathrm{Fe}^{2+}$ with distance from shore. 


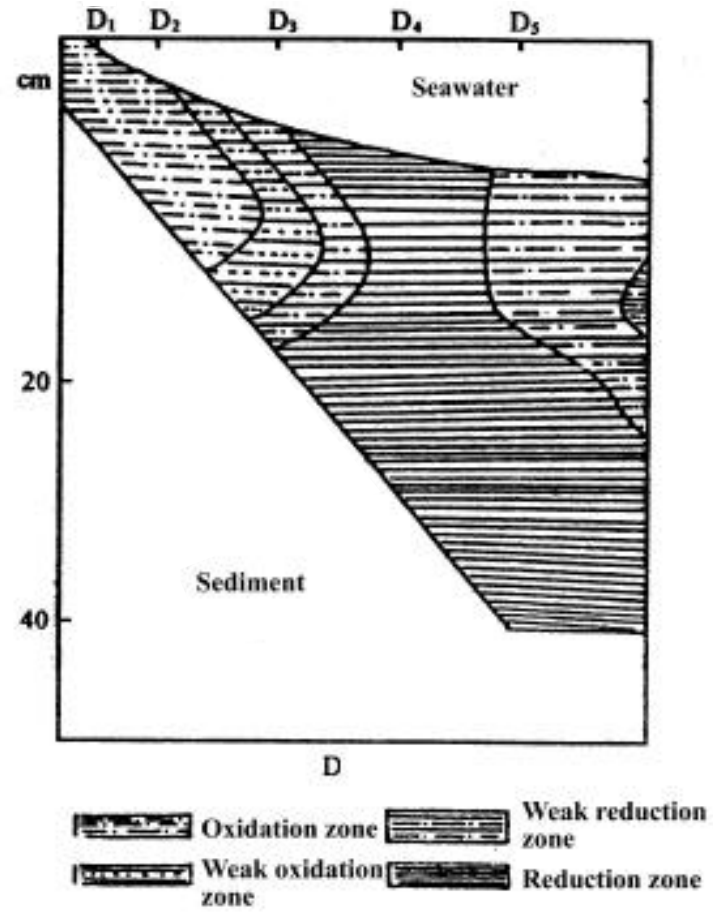

Figure 3. ROD distribution of seabed sediments along D section.

Sediments at the two stations were mainly composed of coarse sand containing a little water, which raised the oxidation-reduction degree.

The surface and bottom layers at D3 station were basically within the weak reduction zone, whereas the middle layer was in the weak oxidation zone, and so, had relatively high oxidation tendency, which related to a high $\mathrm{Fe}^{3+} / \mathrm{Fe}^{2+}$ value in the $10-15 \mathrm{~cm}$ depth. The D4 station sediment layer was in the reduction zone. D5 station was in the weak reduction zone in the surface layer and in the moderate reduction zone in the deep layer, which is in conformity with the curve in figure $2 \mathrm{f}$ of $\mathrm{Fe}^{3+} / \mathrm{Fe}^{2+}$ variation with distance from shore. Change in Es also had certain effect on it. At the same time, because the mud layer at D5 station was very thick, water content change was an important factor in determining the oxidationreduction degree.

Figure 4 shows the horizontal distribution of ROD of the surface sediment and $10-15 \mathrm{~cm}$ layer in this sea area.

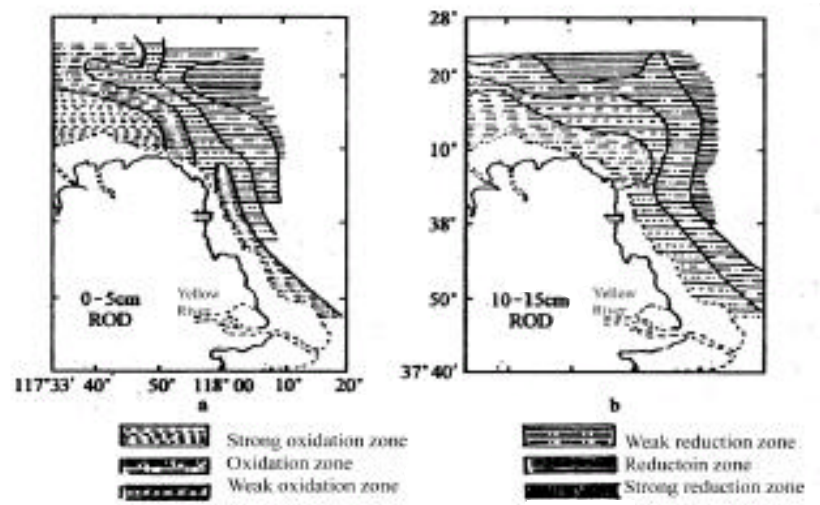

Figure 4. ROD of sediments in the northern sea area off the Huanghe River mouth.

In general, the transition occurred gradually from oxidation and weak oxidation to weak reduction and reduction, indicating that the farther it was from the coast, the stronger was the reducibility of the environment, while the nearer it was to the coast, the stronger was the oxidizability of the environment. Thus, for steel structures in seabed sediment of offshore coastal waters, the distance from the coast is the main factor affecting its corrosion activity. The nearer it is to the coast, the higher the oxidizability of the environment, and the more liable for metal to corrode.

For the same station, viz. the sediment corrosion environment at the specific place, corrosivity differed with depth. Es at the deep layer was lower than that at the surface, and related to the activity of sulfate reducing bacteria (SRB). At different depths in seabed sediment, the oxygen difference cell induced by uneven oxygen diffusion was also an important reason for the different corrosivity.

\section{References}

Gu Hongkan 1991 Marine chemistry of Bohai Sea, Huanghai Sea and Donghai Sea (Beijing: Science Press)

Hou Baorong 1981 Stu. Mar. Sinica 1887

Li Yantao and Hou Baorong 1997 Oceanol. Limnol. Sinica 28 179

Song Jinming 1997 Sediment-seawater interface chemistry of China seashore (Beijing: Ocean Press) 